\title{
For mothers and sisters: care of the reproductive female body in the medico-ritual world of early and medieval Japan
}

\section{Katja Triplett $(*)$}

(*) Department of East Asian Studies, The Study of East Asian Religions, University of Göttingen triplett@uni-goettingen.de

Dynamis

[0211-9536] 2014; 34 (2): 337-356

http://dx.doi.org/10.4321/S0211-95362014000200004
Fecha de recepción: 22 de febrero de 2013

Fecha de aceptación: 7 de febrero de 2014

SUMMARY: 1.-The heterogeneity of the Sino-Japanese medical system. 2.-The Ishinpō: a compilation of coveted medical knowledge. 3.-Fascicles on women's health. 3.1-Women's diseases. 3.2.-Continuation of Women's diseases. 3.3.-Obstetrics. 4.-Buddhist views of women and female bodies. 5.-Corporeality and virtue. 6.-Mothers or sisters: different concerns for the reproductive female body.

ABSTRACT: While married female members of the Japanese aristocracy followed the ideal of bearing children, female Buddhist novices and ordained women, often belonging to the aristocracy themselves, had to abstain from sexual activity and reproduction in accordance with the ordination rules. Infertility was considered with disdain by the first group, whereas not bearing children was the utmost expression of leading a virtuous life for the second group. However, both groups were concerned with keeping their physical bodies healthy: some to become mothers, the others to live as nuns or religious sisters. Focusing on the early medieval period, this paper examines various sources to illuminate the ways in which women were cared for and the kind of views and ideas that informed this care. Instead of looking at the ancient methods of treatment through a modern «scientific» lens and sorting them into «proto-scientific» and «superstitious» categories, medico-ritual and religious views on the female body are explored as facets of the worldview prevalent in the period under consideration. Special attention is paid to relevant chapters of the first medical work produced in Japan, the Ishinpō, compiled by a court physician, Tanba no Yasuyori, in the late 10th century CE. The investigation of other sources, such as Buddhist legends and doctrinal texts, suggests that women were recommended to seek to overcome their femaleness altogether by transforming their female bodies into male bodies in order to reach ultimate "healing» in terms of salvation. In lay circles, however, the Buddhist divinities and other powerful deities were worshipped to ensure this-worldly «healing» in terms of successful procreation and continuation of the family line.

PALABRAS CLAVE: Ishinpō, budismo, obstetricia, salvación, mujeres, Japón medieval.

KEY WORDS: Ishinpō, Buddhism, obstetrics, salvation, women, medieval Japan. 


\section{The heterogeneity of the Sino-Japanese medical system}

When the oldest Japanese medical work, the Ishinpo 㭱心方 $^{1}$, was compiled in the 10th century CE, Japan had been a country deeply influenced by Buddhist teachings for four centuries. The ultimate goal in Buddhism - that of attaining buddhahood and obtaining insight into the nature of all beings - seems at first sight to be quite aloof and disconnected from the daily toil and worries of the ordinary men and women. Still, in East Asian Buddhism, many teachings and practices were and continue to be connected to immediate and worldly concerns such as healing disease and addressing health and physical safety in various ways as well as expressing wishes and guidelines for a safe pregnancy and delivery. Numerous East Asian Buddhist texts provide Āyurvedic as well as Chinese medical prescriptions and instructions to heal the physical body in combination with Buddhist liturgical and ritual practices ${ }^{2}$. Initially, knowledge of healing from different, but not separate, traditions was transmitted jointly from the continent to Japan beginning in the 6th century CE. In modern view, the strands of Chinese medical tradition with its application of acupuncture and moxibustion and the tradition of Buddhist spiritual healing in terms of salvation from suffering, could be regarded as not only separate but also as somewhat mutually exclusive. Chinese medicine seems to be in contrast to Buddhist healing practices because Chinese medical texts are viewed as being «secular» or «non-religious» and not aimed at leading all humanity to salvation ${ }^{3}$. A closer look at the Ishinpo reveals, however, that this categorization into «secular» Chinese medicine and «religious» Buddhist healing practices is oversimplified, for the Ishinpō, usually regarded as a compilation of secular «Chinese medicine», quotes numerous texts from the Buddhist world ${ }^{4}$. Moreover, the Ishinpo recommends the use of talismans and rituals derived from the Daoist tradition, as will be shown in more detail

1. Written also: 醫心方.

2. Triplett, Katja. Magical Medicine? - Japanese Buddhist Medical Knowledge and Ritual Instruction for Healing the Physical Body. Japanese Religions (Special Issue: Religion and Healing in Japan, ed. Christoph Kleine and Katja Triplett). 2012; 37 (1-2): 65. The content of the present article is based on the research for the quoted study and is therefore cited extensively below.

3. Triplett, n. 2, p. 70, passim.

4. Ma, Jixing [Ma Keikō] 馬継興. «lshinpō» chūteki koigaku bunken shotan 『医心方』中的古医 学文献初探. In: Ishinpō: issen-nen kinenshi 醫心方: 一千年記念誌. Tokyo: Ishinpō issen-nen kinenkai 医心方一千年記念会; 1986; Triplett, n. 2, p. 71-72. 
below in connection with care for the female body. The Ishinpo is thus a combinative work providing court physicians with all options available at the time for ensuring or recovering health and well-being of court nobility. Whereas the knowledge encapsulated in the Ishinpo was jealously guarded for centuries to preserve positions of power held by these guardians of what I call medico-ritual knowledge, Buddhist monk physicians (sōi 僧医) were in a way more generous with sharing such knowledge - but by no means open-handed. The reason is that the court and the temples were intrinsically linked by family bonds, and despite the concern for the salvation of all living beings, to keep the power in the circle of blood relatives seems to have been a most immediate concern of these monks.

However, there was also another group of agents in the Buddhist milieu in early and medieval Japan that contributed profoundly to the field of Buddhist healing. Groups of novice monks and nuns not belonging to the official Buddhist elite and performing from vocation, acted as «miracle workers» in the populace ${ }^{5}$. Moreover, early Buddhist legends on karmic retribution were widely used in proselytizing ${ }^{6}$. Not only acute or chronic diseases would be healed miraculously by adhering to the practice and worship of certain Buddhist deities but those born with bodies viewed in the sources to be deficient - such as female bodies- would still be able to attain the final goal of buddhahood. Overall, such legends attempted to lend credence and provide evidence for the superiority of Buddhist teachings and practices newly introduced to Japan.

The Ishinpō and Buddhist legends of karmic retribution clearly aimed at different goals: the first was to keep members of the Japan's elite healthy (and thereby the whole state), the second was to convert the populace (again, the whole state) to Buddhism. The healing rituals developed and practiced by Buddhist monks and nuns in various parts of East Asia, therefore, should be seen in the context of personal or universal salvation. From a point of view of modern systems theory, the activities of physicians and of Buddhist monastics belong to different systems. In his systems theory Niklas Luhmann stresses the difference between sickness and suffering, and health and salvation in functionally differentiated societies ${ }^{7}$. According to

5. Triplett, n. 2, p. 74, 75-77.

6. Triplett, n. 2, p. 70.

7. «To connect disease (illness) and health is different from connecting suffering and healing (wholeness)» (transl. by author). The original quote is: «Von Krankheit auf Gesundheit hin 
Luhmann the system of religion does fulfill functions that are also addressed by other systems albeit in a different way. For instance, Buddhist healing rituals and the application of medication taken from the «secular» system of medicine, aim at alleviating fear of the indeterminacy of sickness and health. However, this takes place within the system of religion with its dichotomy of suffering - salvation ${ }^{8}$.

Since both physicians and Buddhist «monk doctors» shared the same world in early and medieval Japan, both kinds of sources -medico-ritual compendia as well as legends and sütras (doctrinal and liturgical texts)provide excellent material for comprising a history of varied ideas about the female body and specific concerns adhering to it, which is the main focus of this article. First the Ishinpō is introduced in some detail as a source for medical and ritual instruction for the care of expectant mothers, followed by a brief consideration of sources that express prevalent Buddhist views of women and female bodies.

\section{The Ishinpō: a compilation of coveted medical knowledge}

The title Ishinpō can be translated as «Essentials of Medical Treatment». It is still extant today but only in a few fairly late versions. Apparently, though, over the centuries, copies were rarely made, due to the tendency to jealously guard these texts and not share them with other clans. Only recently has there been a complete translation into modern Japanese and critical text edition of the entire thirty-fascicle work. Maki Sachiko, the foremost specialist on the Ishinpō in Japan, published this edition in 1993. Before, some fascicles were selected and transmitted separately, especially fascicle 28 on «Health Principles and Chamber Exercises».

Content of the Ishinpo ${ }^{9}$

1. Disease treatment, pharmacology, posology

zu denken, ist etwas anderes als von Leid auf Heil,» Luhmann Niklas. Funktion der Religion. Frankfurt am Main: Suhrkamp; 1982, p. 193.

8. Kleine, Christoph; Triplett, Katja. Introduction to «Religion and healing in Japan». Japanese Religions (Special Issue: Kleine, Christoph; Triplett, Katja, eds. Religion and healing in Japan) 2012; 37 (1-2): 1-3.

9. The translation of the table of contents follows Hsia, Emil C. H.; Veith, Ilza; Geertsma, Robert H. The essentials of medicine in ancient China and Japan: Yasuyori Tamba's Ishimpō, translated with 

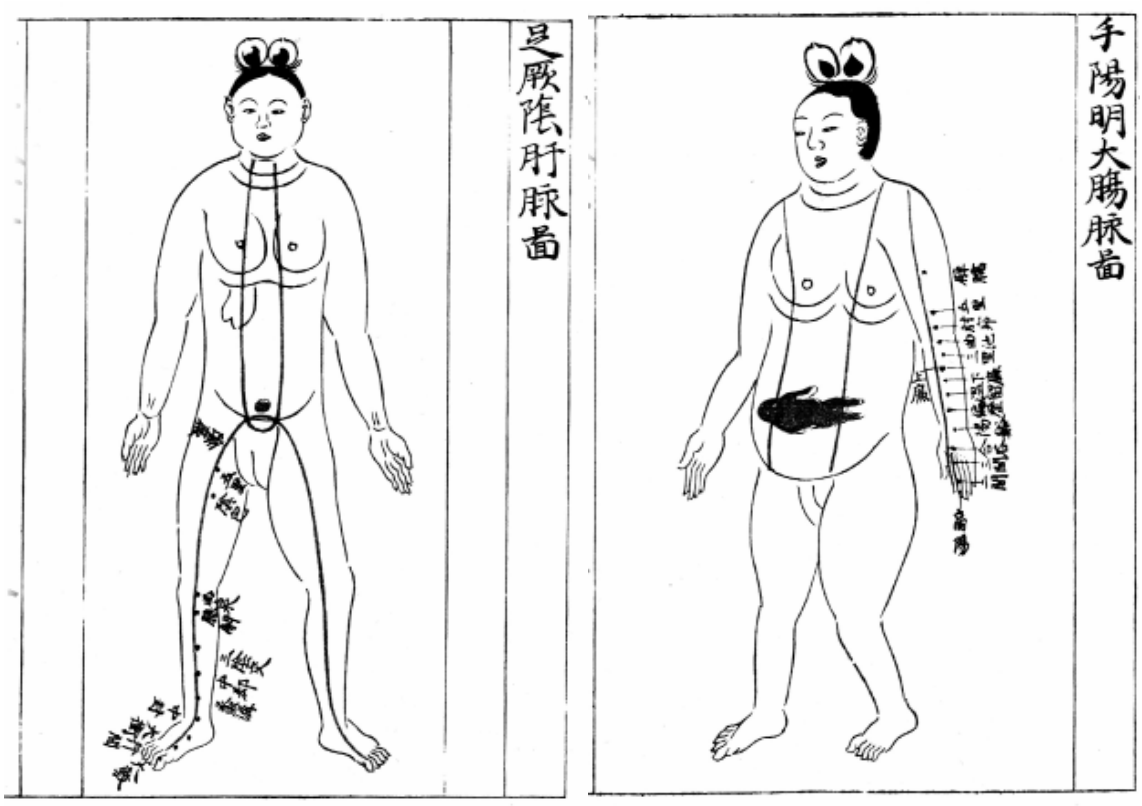

Figs. 1 and 2.- Illustrations from the Ishinpo showing an unclad woman in the first and eighth month of pregnancy respectively, the state of the foetus in her womb, and acupuncture lines. Some parts of the images in the facsimile edition are rendered in red as intended by Tanba Yasuyori. Source: Ishinpō. Nihon koten zenshū, vol. 5 of 7; 1935, p. 1965 and p. 1979.

2. Acupuncture and moxibustion

3. Afflictions of the nervous system (wind strokes)

4. Whiskers, hair, face, nose, body odours

5. Eyes, ears, mouth, tongue, teeth

6. Internal organs, stomach, heart, kidneys, liver, lungs

7. Genitals, piles, intestinal worms

8. Nutritional deficiency, diseases of the extremities

9. Cough, asthma, dyspepsia, nausea

10. Hernia, jaundice, swelling

11. Cholera and dysentery

introduction and annotations. Leiden: Brill; 1986. The English translation by Hsia et al. contains fascicle 28 as well as fascicles 1, 2, 26 and 27. Fascicle 28 was published separately: Ishihara, Akira; Levy, Howard S. The Tao of sex: An annotated translation of the twenty-eighth section of the essence of The essence of medical prescriptions (Ishinpō). Yokohama: Shibundō; 1968. 
12. Constipation, diabetes, haematuria, bedwetting

13. Consumption, exhaustion, bone and lung disease, insomnia

14. Sudden death, remittent fever, typhoid fever, drowning, freezing

15. Boils, growths in lungs and intestines

16. Carbuncles, vicious swellings, varicose veins

17. Skin diseases

18. Wounds, burns, metal wounds, arrow wounds, falling from horses, dog bites, horse bites

19. Various types of tonics, mineral diet

20. Antidotes for mineral-dietary poisoning

21. Women's diseases

22. Continuation of women's diseases

23. Obstetrics

24. Conception, prediction of sex, pregnancy tests

25. Paediatrics

26. Geriatrics, attaining longevity

27. Geriatrics, mental hygiene, breathing exercises

28. Health principles, chamber exercises

29. Dietary adjustments

30. Materia medica: Grain cereals, fruit, meat, vegetables

The Ishinpō is comprised of medical writings from China, Korea and India and quotes extensively from Japanese prescription manuals. In 984 Tanba (no) Yasuyori 丹波康頼 ${ }^{10}$, a court physician of Chinese or Korean descent ${ }^{11}$, selected passages mainly from pre-Tang period Chinese literature and other sources and compiled the thirty-fascicle medical work which he finally presented to the imperial court.

The best-preserved copy of the so-called Nakarai-bon 半井本 (1532), a rarely seen national treasure was finally copied, printed and published by the Government Institute of Medicine in 1860. Even after the publically available print edition, the scrolls themselves were preserved in a closed archive until the Imperial Household Agency purchased them in 1982. The Ishinpo , with its 1.088 quotations from altogether 204 different sources ${ }^{12}$

10. Please note that the name is given in modified transcription as «Tamba»; often the name does not contain the particle «no».

11. Hsia et al., n. 9, p. 10.

12. Ma, n. 4 . 
is a great textual mosaic. Some of these sources have been subsequently lost; their fragments can only be found in this compilation. Apart from Chinese classical medical texts and some works originating in Japan, the Ishinpō quotes numerous Buddhist sources, which is remarkable and not noted in most modern studies because of the strong emphasis on so-called secular classical Chinese medical studies thought by modern scholars to be proto-scientific or quite close to what we call scientific biomedicine. Maki Sachiko does see fundamentally a proto-scientific character of the early sources quoted in the Ishinpō, and dubs ritual and talismanic treatments rather as «superstitious» as we can see in her chapter introductions. This categorization of health measures into «scientific» (and therefore acceptable) and «superstitious» (and therefore unacceptable or at least questionable) is in my view problematic. The Ishinpō shows that ritualistic treatments and therapies involving administration of medicine were intrinsically linked, and it does not help our understanding of the early and medieval cultural history to subject the measures and actions taken to modern value judgements.

\section{The fascicles on women's health}

Three fascicles of the Ishinpo concern women's health in particular:

21. Women's diseases

22. Continuation of women's diseases

23. Obstetrics ${ }^{13}$.

Also Fascicle 24 on «Conception, prediction of sex, pregnancy tests» regards women's physical issues. As Fascicle 21, 22 and 23 show, medication and treatments geared towards women's bodies and sensibilities regarded as different from men's, were considered carefully in China 1400 years ago.

13. For a study of the culture of childbirth in China that makes frequent use of these sources see Lee, Jen-Der. Childbirth in Early Imperial China. Nan Nü. 2005; 7 (2): 216-286. 


\subsection{Women's diseases}

The main points in Item 1 of Fascicle 21 contain descriptions and treatments of polyps or tumours in breasts and the womb that are leading concerns of modern medicine. The term «cancer» ( $g a n$ 癌) for these pathological growths did not exist yet. The disease was termed gan, using the character 岩, in the Edo period (1603-1868) ${ }^{14}$. Nevertheless, from the explanations of the symptoms it can be assumed that Tanba no Yasuyori describes what we now call cancer. In cases where women contract an acute inflammation of the mammary glands, mastitis, after a first birth or before nursing, they are treated by fastening of a plaster on the breast after a medicinal bath, fomentation or poulticing (anpō 罨法), the application of ointments and the administration of medicine taken internally as well as moxibustion.

\subsection{Continuation of Women's diseases}

Fascicle 22 was transmitted separately and perhaps because of this contains some oddities. Tanba no Yasuyori originally compiled this text on women's diseases in 984 when he was 82 years old, for the very recently abdicated Emperor En'yū 円融 (r. 969-984) ${ }^{15}$. Apparently, this work was transmitted separately from the other fascicles for centuries and rejoined only in 1982 when it was purchased by the Japanese state from private owners, the Nakarai family. There are two theories for this unusual path of transmission. The first is that a disciple of Nakarai Zuisaku 半井瑞策 from the Okamoto clan obtained this fascicle in order to save his master's daughter from serious illness afterchild birth, and it was then transmitted to Okamoto Yūken 岡 本由顕. The other is that Okamoto borrowed the scroll from Zuisaku but never returned it. These scenarios are unlikely, but in the end the Okamoto family, one of the Kyoto medical clans, sold the scroll with Fascicle 22 as a separate work in the middle of the Edo period (ca. 18th century) in a time of decline of the family fortunes to the Nishikikōji 錦小路 family who

14. Maki, Sachiko 梖佐知子. Ishinpō: Maki Sachiko zenshaku seikai 医心方: 梖佐知子全訳精解. Vols. 21, 22 and 22. Tokyo: Chikuma shobō 筑摩書房; 1993, Vol. 21, p. i.

15. Maki, n. 14, Vol. 22, p. i. 
descend from the Tanba clan ${ }^{16}$. It was then passed on further and finally obtained the status of a national treasure and became reunited with the other scrolls ${ }^{17}$.

Moreover, in the version from 1854 (Ansei era year 1 安政元年) only this Fascicle 22 renders parts of the drawings in red whereas all other drawings are monochrome. Other versions have red ink in their illustrations as well ${ }^{18}$. The fascicle contains a text that was referred to separately as the «Classic on Obstetrics» (Sankyō, Chin. Chănjing 産経), a Sui dynasty text that is now completely lost in China.

Fascicle 22 is divided into 37 items pertaining to the special treatment of pregnant women with acupuncture and moxibustion, care of the foetus, preventative care before the onset of birth, morning sickness, dropsy, frequent urination, fever, coughing, backache and other ailments that may befall a pregnant woman. The last item, number 37, describes how to abort the foetus to save the mother's life ${ }^{19}$.

The most outstanding feature of this fascicle is the remarkable illustrations of women in different stages of pregnancy ${ }^{20}$ (Images 1 and 2). The drawings illustrate the monthly advance of pregnancy with the growing foetus inside the womb of an entirely unclad woman. Since pregnancy was in East Asia divided into ten months ${ }^{21}$, the text includes ten pictures in all. These are exceedingly singular examples of images of a growing foetus that are rarely seen in sources from the ancient period.

The hair-style of the pregnant woman with two knots to the side of the face that resemble a Chinese women with an ancient dance (gigaku 伎楽) mask was popular in the Sui Dynasty period (581-618 CE). It is believed that Tanba had an artist insert the images from the "Classic on Obstetrics» (Sankyō) into his compilation copying an early version of that work. They remain the only evidence of the images in the lost Chinese text on birth ${ }^{22}$.

16. Considering that the Tanba clan had historically been in fierce competition with the Nakarai this purchase must have been a triumphant affair.

17. Maki, n. 14, Vol. 22, p. iii.

18. Maki, n. 14, Vol. 22, p. iii.

19. Maki, n. 14, Vol. 22, p. vi.

20. See e.g. in the following facsimile edition: Tanba, Yasuyori 丹波康頼. Ishinpō 醫心方. Nihon koten zenshū 日本古典全集; ed. Masamune, Atsuo 正宗敦夫. Tokyo: Nihon koten zenshū kankōkai 日本古典全集刊行會; 1935.

21. Choo, Jessey J. C. That «Fatty Lump»: Discourses on the fetus, fetal development, and filial piety in China before the eleventh century CE. Nan Nü. 2012; 14: 180.

22. Maki, n. 14, Vol. 22, p. iii-iv. 
According to Maki Sachiko, much advice from modern times for pregnant women indeed points back to this fascicle such as «one should not lift heavy objects in the early stage of pregnancy» or «one should not eat stimulating food ${ }^{23}$. The influence on medieval court culture was so great, she claims, that although the exact nature of the influence is difficult to determine «it is not an exaggeration to say that if you removed Chinese medicine, there would be no Japanese court culture» ${ }^{24}$. Maki is eager to point out continuities and developments in the field of Asian medicine following an evolutionary model from a lower, 'primitive' to a higher, advanced level. This is especially evident in the passage on food taboos. Food taboos for pregnant women are also prevalent in modern Kanpō 漢方 (Chinese style) medicine, and many of these taboos derive directly from the $10^{\text {th }}$ century text, as she can show. Maki declares these to be «superstitious» (meishinteki 迷信的) for the most part, quoting James George Frazer (1854-1938) with an unmarked passage to show that these food taboos are indeed connected to superstition ${ }^{25}$. The original passage is from Frazer's opus magnum «The golden bough»:

«As might have been expected, the superstitions of the savage cluster thick about the subject of food; and he abstains from eating many animals and plants, wholesome enough in themselves, which for one reason or another he fancies would prove dangerous or fatal to the eater» ${ }^{26}$.

As is well known, Frazer saw certain elements of behaviour in modern, civilized societies that he interpreted as pointing back to ancient, primitive ideas when the human mind - the mind of the «savage»- was still developing and trying to achieve an orientation in the natural environment. He also studied reports and studies of contemporary ethnic groups and nations thought to be «primitive» such as certain peoples of Australia and Africa, in order to present his evolution of the human intellect. Frazer's evolutionary scheme posits superstition and magic at the beginning, to be followed by religion, with overlapping states of «fusion or confusion» of the two, and culminating in science. However, he evades the issue of whether science

\footnotetext{
23. Maki, n. 14, Vol. 22, p. v.

24. Maki, n. 14, Vol. 22, p. v.

25. Maki, n. 14, Vol. 22, p. iii-iv.

26. Frazer, George. The golden bough: A study in magic and religion, Part II. London: Macmillian; 1927 [1911]. Chapter V (Tabooed Things), § 10 Foods tabooed, p. 291.
} 
makes religion eventually obsolete. Frazer's rendering of magic as mistaken (superstitious) is highly problematic because his view of truth belongs naturally to his own frame of reference that is informed by linguistic, social and cultural propositions, and thus a proper test to verify the statement could not possibly be performed. Frazer does not explain the meaning of the rituals and myths; he arranges the so-called facts in a schema only to point out a hypothetical temporal lineage of human mental conditions. Trained in classical studies and archaeology he goes to great pains in dividing magical practices found in textual sources ${ }^{27}$ into various subcategories, including various subcategories of taboos ${ }^{28}$. Academic researchers still use them as if they were factual and not arising from Frazer's personal ideas on the «savage», especially in folklore studies in the «West» ${ }^{29}$ but also, as we just saw, in Japan. In my opinion, the question of whether or not food taboos for pregnant women were physically harmful, ineffective or helpful from a modern medical point of view cannot methodologically be part of a study on cultural and religious history. The fact is, that the sources recommend certain food regimens to these women, and this tells us about deep concerns of those having lived in a long past world.

Apart from a total of 82 kinds of medicinal remedies that must not be administered to pregnant women, Fascicle 22 recommends medicines that cannot be taken at all but are applied in the form of prayers and rituals in the case of noble women ${ }^{30}$.

27. Evans-Pritchard calls Frazer's method «scissors-and-paste method of compilation» in: EvansPritchard, Edward E. Theories of primitive religion. Oxford: Clarendon Press; 1970 [1965], p. 9, satirically ridiculed by Malinowski in: Malinowski, Bronislaw. Crime and custom in savage society. London: Paul; 1926, p. 126.

28. Frazer lists tabooed acts, persons, things and words in Part II (Taboo and the perils of the soul) of his «Golden Bough».

29. See for example: Hand, Wayland D. Magical medicine: The folkloric component of medicine in the folk belief, custom and ritual of the peoples of Europe and America. Berkeley, Calif. [et al.]: University of California Press; 1980, p. 171-172. A discussion of this is found in: Georges, Robert A.; Jones, Michael Owen. Folkloristics: An introduction. Bloomington [et al.]: Indiana University Press; 1995, p. 57, n. 40.

30. Maki, n. 14, Vol. 22, p. vi. 


\subsection{Obstetrics}

In general, birth and death had the most rituals and regulations (taboos) in early East Asia. Fascicle 23 with its 50 items is the best example of the thought and imagery connected to birth in early China that was later introduced to Japan. Many passages in this fascicle detail rituals and actions aiming to prevent spiritual pollution or to purify the polluted woman with the help of talismans, and paying attention to the cosmic order. Special attention is paid to the site where the birth is to take place. The parturition chamber is ritually purified and certain auspicious deities are summoned to guard the cardinal directions against evil influences. The text mentions the Twelve Gods (Jūni-shin 十二神) in terms of the deities of the twelve stems (jünishi 十二支) of the Chinese cosmological system ordering space and time. In addition to these, the Eight Generals (Hasshōgun 八将軍) play a major role in keeping the birthing chamber pure and protected ${ }^{31}$. In Japan, the father of the Eight Generals, deities originally from Northern India, was identified with Gozu-tennō 牛頭天王, also called Mutō-shin 武塔神, who we find in turn combined with the image of the Shinto god Susanoono-mikoto 須佐之男命 in the early modern period. The mother of these eight divine children ${ }^{32}$ is the daughter of the dragon king Sagara 乷謁羅 33, Toshitoku-jin 歳徳神, an important directional deity who is revered as the goddess of the New Year. We can clearly see that the original Chinese divinatory yin-yang and calendrical systems with their pantheon of divinities had been adapted to Japanese religious and cosmological ideas to ensure a safe birth of a healthy child.

In China, protective talismans from Daoist sanctuaries played an important role in giving masters the secret powers to conduct an effective ritual $^{34}$. This idea was transferred to the Buddhist sūtra texts. The healing power was transferred to the brush by blowing on it. In the Ishinpo there are talismanic texts in red and black characters provided originally by Tanba

\footnotetext{
31. Maki, n. 14, Vol. 23, p. ii

32. For a list of all eight deities see Maki, n. 14, Vol. 23, p. ii and ix for an exhaustive list of all deities mentioned in Fasc. 23.

33. Alternatively written 娑竭羅 and read Shakatsura.

34. Maki, n. 14, Vol. 23, p. iv-v. For the overall exposé on the Daoist traditions, including the use of talismans, see Kohn, Livia, ed. Daoism Handbook. Handbook of Oriental Studies, China Part 4: 14. Leiden: Brill; 2000.
} 
no Yasuyori ${ }^{35}$. For example, a passage from Item 9 on «Difficult Births: Prevention and Healing Methods» in Fascicle 23 instructs us to write an especially efficacious character with vermillion (shu 朱) ${ }^{36}$ and swallow it for healing ${ }^{37}$. Another method is to burn the vermillion in which the character is written and take it as a medicine. Then, it says, the birthing process will start soon. The character is written on the afflicted part, possibly here the belly, or it could have been written on paper, which is then stuck on the belly. The paper can be easily removed and burned, and the ashes used for medicinal purposes.

Often, talismans are used and the treatment is accompanied or consists of spells but we learn from the text that they only take effect when combined with medicinal herbs ${ }^{38}$. The "spells» are of different character. They can be blessing formulae (iwai 祝) such as the one in Section 10 in Item 9 that recommends the following to be uttered in a difficult birth situation:

«The Heavenly sky above is blue, so blue, the Earth below is abundant with greenery, all for the subjects of the Emperor. Why do you not come out? Quickly come out, quickly come out, the Emperor is at the door. This is why N.N. must come out quickly, come out quickly» ${ }^{39}$.

Tanba no Yasuyori frequently lists spells ensuring a safe birth from the Buddhist world, the popular dhāranī (darani 陀羅尼, or ju 呪) that consist of long rows of Sanskrit syllables that usually do not form a sentence. Instead, the sound of the syllables «holds» the healing power of the deities. For instance, he quotes dhäranī from a work called Daishū darani-kyō shinju 大集陀羅尼経神呪 which is probably, as are other Buddhist spell collections in the Ishinpō, not of Indian origin but written in China ${ }^{40}$. It may have even been created in Japan.

The assumption that the recurrent quoting of Buddhist sources, especially in the fascicle on obstetrics, and the inclusion of Buddhist spells point to a significant influence of Buddhist thought on the Ishinpō, needs to be discussed further. The question is whether Tanba no Yasuyori

35. Maki, n. 14, Vol. 23, p. iv; Triplett, n. 2, p. 72.

36. Vermillion, natural mercuric sulphide, was used in healing potions for boils until early modern times but in the modern period its use was discontinued because of its toxicity.

37. Maki, n. 14, Vol. 23, p. 86 .

38. Maki, n. 14, Vol. 21, p. ii

39. Maki, n. 14, Vol. 23, p. 84

40. Maki, n. 14, Vol. 23, p. iii, Triplett, n. 2, p. 72. 
just included any technique or method thought helpful in his compilation to provide a complete, encyclopaedic manual for court physicians of his clan, or whether the work is suffused with a Buddhist outlook on life, death and healing in terms of salvation. When looking at the networks of individuals and institutions that produced, transmitted and circulated medical knowledge, the Buddhist influence on medical practice in Japan was -in my view - significant ${ }^{41}$. In order to evaluate this question it is necessary to look at Buddhist views of the female body and reproduction prevalent in Tanba no Yasuyori's time.

\section{Buddhist views of women and female bodies}

In early Buddhist scriptures, starting in the 2nd century BCE, the female body is described as being handicapped by its reproductive physiology, i.e. by menstruation, pregnancy and delivery. This view is frequently repeated in different parts of Buddhist scriptures over the centuries in the context of different cultures and societies, also in Japan, where Buddhism entered in the 6th century CE. Is this view then an intrinsically Buddhist idea? Or does it mirror the views of the men and women of the specific culture where the Buddhist teachings were adapted - the view that female bodies are deficient and that humans in these female bodies are unable to obtain enlightenment and the perfect body of a Buddha? The idea that women cannot attain buddhahood is the subject of academic studies, such as the works by Miriam Levering on the Buddhist narrative passage from the Lotus Sütra on the young nāga (snake or dragon deity) princess, a female non-human being, who transforms into a male, an enlightened being and finally obtains buddhahood, all in an instant ${ }^{42}$. This well-known motive of the Lotus Sütra - a most influential and culturally important Buddhist scripture-dominated the world of ideas about women's enlightenment for centuries, as can be seen from the inclusion of this motif in popular narratives in medieval and early modern Japan ${ }^{43}$. But not all Buddhist writings refer to

\footnotetext{
41. See Triplett, $n$. 2 for an elaboration on this.

42. See for example Levering, Miriam. The dragon girl and the abbess of Mo-Shan: Gender and status in the Ch'an buddhist tradition. Journal of the International Association of Buddhist Studies. 1982; 5 (1): 19-35.

43. Triplett, Katja. Menschenopfer und Selbstopfer in den japanischen Legenden: Das Frankfurter Manuskript der Matsura Sayohime-Legende. Münster: Lit; 2004, p. 109-110.
} 
this motif. There are other ideas that have inspired lively discourses on the nature of women and the possibility of attaining buddhahood in their female bodies ${ }^{44}$. One obstacle quoted frequently is that the body of a Buddha is male since one of its characteristic features is an indrawn penis - a symbol of the complete overcoming of sexual activity and thus detachment from worldly desires. An influential Zen Buddhist thinker, Dōgen Kigen 道元 希玄 (1200-1253), wrote repeatedly that the path to enlightenment is open to both men and women, and that from the point of view of the absolute truth - the basic tenet of East Asian Buddhism is the exposition of a relative (mundane) and an absolute truth - categories such as male and female are totally meaningless. This abstract exposition was known, at least in the world of Zen Buddhism, but still, on the mundane level, the members of human society struggled with the idea that women may be sinful because of their reproductive and therefore potentially extremely «impure» bodies and thus may be barred from ultimate healing and salvation if countermeasures were not met.

In this light, it is understandable why an apocryphal sūtra dedicated solely to the transformation of the female body was so popular: «The Sütra of the Buddha's Sermon on Transforming the Female Body» (Bussetsu tennyoshin-kyō 佛説轉女身經 $)^{45}$, translated in the Sui Dynasty. In this sūtra, the actual origin of the particular suffering of women is ascribed to one hundred worms that live in the female body. These worms cause the suffering of women and are the reason of their basic defilement. The worms resemble what we would call germs and could be interpreted as the cause of a diseased body. This means that the sutra suggests that the female body is not essentially defiled but inflicted with harmful germs. Thus, it is a body that can be ultimately «healed». If the worms were removed, the female body would be freed from these originators of suffering. However, it seems that only female bodies are inflicted with these hundred worms thus depicting

44. Ruch, Barbara, ed. Engendering faith: Women and buddhism in premodern Japan. [Michigan monograph series in Japanese studies n.0 43]. Ann Arbor: Center for Japanese Studies, University of Michigan; 2002. For an in-depth discussion of «problematic passages» in canonized Buddhist writings in Japan see: Heidegger, Simone. Buddhismus, Geschlechterverhältnis und Diskriminierung: Die gegenwärtige Diskussion im Shin-Buddhismus Japans. Münster: Lit; 2006, p. 53-66.

45. Translated by Dharmamitra (356-442), standard edition see: Taishō shinshū daizōkyō 大正 新修大藏經. 1924-1935. Takakusu Junjirō 高楠順次郎; Watanabe Kaigyoku 渡辺海旭, eds., 100 volumes, number 0564 (= T 0564). 
them as vulnerable and weak. According to the sūtra, recitation of the sūtra and spells will surely result in the transformation of the female body.

A second sutra, composed in China in the late 12th century, concerns coping with a negative view of the female body, here because of women's reproductive functions. Although it is a fairly late apocryphal work, it may be surmised that the basic thoughts existed already in $10^{\text {th }}$ century East Asian Buddhism. This important sūtra is the non-canonical «The Buddha's Correct Sūtra on the Bowl of Blood» (Bussetsu daizō shōkyō ketsubon kyō 亿説大 蔵真経血盆経) that also gained wide ascendency in Japan. It is popularly referred to as the «menstruation suttra ${ }^{46}$ and is based on the understanding that women are in danger of being born in a bowl or pond filled with blood, symbolizing the blood shed in menstruation and parturition. Reciting and keeping the sütra as a talisman can prevent this terrible fate.

As we can see, although Buddhist sūtras and teachings provide ways of overcoming the affliction of being born in a woman's body; still it is seen essentially as an affliction. If a woman requires medical treatment, does this mean that she is fundamentally deficient? Healing therefore would mean not only the healing of a human body, but also of a female body. Ultimate healing of the female body, though, according to the views encapsulated in the three sūtras mentioned above, is healing them of their femaleness altogether.

However, Buddhist canonical literature contains numerous references to diseases and medical treatments, usually in connection to eligibility of receiving ordination as a monk or nun. In the Pali scriptures and ordination texts we find very specific descriptions of gynaecological disorders that render female adepts unfit for ordainment ${ }^{47}$. It explains rules of hygiene for female monastics to prevent conception, for example by accidentally touching clothes of a male monk that is soaked with semen, and describes regimens for menstruating women and the use of vaginal pads for nuns. Abortive and contraceptive medicines are also mentioned. For example, in the catalogue of nascent Buddhist scriptures in China, "Compilation of Notes on the Translation of the Tripitaka» (Shutsu sanzō kishū 出三藏

46. Takemi, Momoko. «Menstruation Sutra» Belief in Japan. Japanese Journal of Religious Studies. 1983; 10 (2-3): 229-246.

47. Jyotirmitra. A critical appraisal of āyurvedic material in Buddhist literature, with special reference to Tripițaka, foreword by G.J. Meulenbeld. Chaukhambha Sanskrit Series. Varanasi: Jyotiralok Prakashan; 1985, p. 363. 
記集) ${ }^{48}$ compiled by the Chinese monk Sēngyòu 僧祐 (445-518) around 515 , we find $4^{\text {th }}$ century guidelines and precepts for nuns including such guidelines of hygiene and medicinal treatment specific to women and based on early Buddhist prescriptions and ideas. With the introduction of the precepts to China, therefore, non-Chinese books on herbal treatments were introduced and translated in the first half of the fourth to the fifth centuries as well. Works such as these were brought to Japan not long after that and were studied by monastic men and women there. The knowledge about how to care for the female reproductive body within the monastic framework therefore circulated widely in early Japan, although more research is required on how this care was actually practiced and how it developed after its introduction.

\section{Corporeality and virtue}

In addition to passages from the scriptures, we also find themes of corporeality and monasticism addressed in Japanese Buddhist legends. Early collections of these legends (setsuwa 説話) relate highly moralistic stories of vice and virtue, and connect familiar as well as imported narratives with a Buddhist message. The oldest and fairly complete extant collection of Buddhist legends in Japan is the Nihon ryōiki, compiled in the early 9th century, is of special interest in the context of views of bodies thought to be deficient. The story about a girl born from a flesh ball, for example (III.19), contains a description of a physical disability:

"[A women in the Higo province of Japan was reported to have given birth to a flesh ball (shishimura 肉團) that looked like an egg. The man and wife not taking it as a good omen stored it in a cave.] After seven days they returned to the cave and discovered that a girl had been born of the flesh ball, breaking through its covering. The parents took her home, and her mother nursed her. There was no one in the province who did not wonder at this. After eight months had passed, she suddenly grew very large, but her head and neck were joined without a chin, in a form different from the other people, and she was three and a half feet high. Endowed with wisdom, she was by nature brilliant. Before she was seven, she recited the Hoke-kyo [the Lotus Sütra] and the Eighty-volume Kegon-gyō [the Flower-Garland Sütra]

48. Taishō shinshū daizōkyō, n. 45; no. 2145.55.110a-102b. (= T 2145.55.110a-102b). 
(...) She was reserved and never boasted. Eventually she decided to renounce the world, shaved her head, and wore a surplice. Prompted by her faith, she practiced good and enlightened people. She had such a good voice that it could lead her audience to become merciful. In her deformed body there was no vagina but only an opening for urine. Foolish laymen mocked her, calling her Saru hijiri (...), False Sage ${ }^{49}$.

The story ends in the triumph of the shunned female cripple. The legend describes what could be seen as perhaps typical modes of discrimination:

«[A certain man from the local gentry held a retreat with the famous] Dharma Master Kaimyō to lecture on the Eighty-volume Kengon kyō [sic] The nun was seated in the audience, never missing a lecture. Seeing her, the lecturer said accusingly, «Who is that nun unscrupulously seated among the monks?» (...) In reply she said, «Buddha promulgated the right teaching out of his great compassion for all sentient beings. Why do you restrain me in particular?» Then she asked a question by quoting a verse from the scripture, and the lecturer could not interpret it. In amazement, all the famous wise men questioned and examined her, but she never failed. [...] In that way they learned that she was an incarnation of Buddha, and named her Bodhisattva Sari [Sari Bosatsu舎利菩薩]. Clergy and laymen revered her and made her their master» ${ }^{50}$.

The nun is clearly a woman but lacks the female sexual organ, so she can be interpreted as being in a stage between female and male. Nakamura interprets the character of the story as indicating a feminizing shift from male-centred discourse in India to a more women-centred discourse in Japan: in India stories tell that boys were born from a flesh-ball, and since no female bodhisattvas were ever mentioned in India, Nakamura says the girl's physical lack of gender can be interpreted as a stage in the process of transition from male to female ${ }^{51}$. A more adequate alternative interpretation is that the text refers to the early Buddhist idea of a separate «monastic gender»: whereas women monastics discard their femininity and reproductive functions and turn

49. Nakamura, Kyoko M. Miraculous stories from the Japanese Buddhist tradition: the Nihon ryōiki of the monk Kyōkai. Monograph series; 20. Cambridge, Mass.: Harvard University Press; 1973, p. 246-248.

50. Nakamura, n. 49, p. 247-248.

51. Nakamura, n. 49, p. 72. 
into beings akin to males, men realize an ideal gender imaged as male minus the sexual drive and desire to reproduce ${ }^{52}$.

The body of the enlightened nun Sari Bosatsu is described in detail as being strongly deformed. She is discriminated against by laymen as a female monastic who does not actually break the rules by sitting among monks at the official religious instruction. She is probably discriminated against also as a cripple, and is continuously mocked as a fraud by those who in actuality envy her for her success. I think this story is similar to the story of the näga princess (näginī) who turns into a bodhisattva. The Lotus Sütra emphasizes the speed of the transformation, but still, the fact that even a non-human, very young female can do it, is supposed to convey awe. Sari Bosatsu despite her outer appearance as a deformed, female dwarf amazes «all the famous wise men» with her insight into the Dharma. Still, both characters, the nāgini and Sari Bosatsu, are both not regular women but rather dharmic beings that are depicted as especially deficient physically to set up a dramatic plot development.

Earlier interpreters of these legends such as Nakamura see women and femininity as symbols. She states in her introduction that the Chinese and Indian view of women as socially and spiritually inferior was not accepted by the compiler, the monk Kyōkai, because «the women in the Nihon ryōiki convey a quite different impression». Kyōkai insists on the equality of all before the dharma ${ }^{53}$. Nakamura writes that in ancient Japan, women had a particular importance as symbols of cosmic power, a role that was exemplified in their procreative function, and that Buddhism added the ethical significance of motherly love to the symbolism of women ${ }^{54}$.

This means, in my view, that because women have a womb and give birth they are regarded as symbols of cosmic power. I am not sure if this was actually so in ancient Japan, or whether it translated into an equal social status. The second part of Nakamura's argument about the ethical significance in Buddhism reduces women to mothers. The first view is connected to corporeality, the second to a role usually gained through

52. Grünhagen, Céline. Geschlechterpluralismus im Buddhismus. Eine Untersuchung zur Tragweite westlicher Wissenschaftskonstruktionen am Beispiel frühbuddhistischer Positionen und des Wandels im theravādabuddhistischen Thailand [doctoral thesis]. University of Bonn; 2011, p. 146; p. 247-249 on the «Sanghageschlecht».

53. Nakamura, n. 49, p. 76.

54. Nakamura, n. 49, p. 76. 
giving birth to a living child, again a connection to the physical dimension. The argument here is that even if a human is a woman, buddhahood can be obtained. That makes the specific teaching appear greater because even deficient or afflicted, impure and sinful humans, i.e. women, can became Buddhas, be born in the paradisiacal Pure Land and so on. The promise is to be able to finally shed the female body for good and thus end suffering.

\section{Mothers or sisters: different concerns for the reproductive female body}

According to Buddhist philosophy in East Asia there are two different but connected levels of truth: the absolute and relative truth. On the absolute level of truth, there are passages in Buddhist discourses that claim that since there is non-duality, being male or female does not matter. On the relative level, in daily life in human society, sex and gender, as well as the issues of safe birth and good health do obviously matter a great deal. These issues were addressed not only in Buddhist canonical literature, but also found their way into compilations such as the Ishinpō. Japanese physicians such as Tanba no Yasuyori combined the ideas of the cosmic order derived from Chinese thought, Buddhist ideas initially developed in India and Central Asia, and thirdly, indigenous ideas of how to lead a healthy and good life with the assistance of powerful guardian and supportive cosmic deities. The absolute level of truth and other philosophical tenets or doctrinal discourses, however, do not play any role in the Ishinpō, although the greater context of uplifting humanity and alleviating suffering may have been discussed by the physicians of the elite and the ordained monks and nuns belonging to the imperial temples.

\section{Acknowledgements}

I would like to express my deep gratitude to the organizers of the the workshop on childbirth and women's health in pre-modern societies held at the Karl Jaspers Centre for Advanced Transcultural Studies, University of Heidelberg on November 4-5, 2011, as well as the Centre for their kind invitation and to all participants for their valuable comments on my paper. 